\title{
Multiple metals and agricultural use affects oxidative stress biomarkers in freshwater Aegla crabs
}

\author{
Presença de múltiplos metais e agricultura afetam biomarcadores de estresse \\ oxidativo em caranguejos de água doce (Aegla)
}

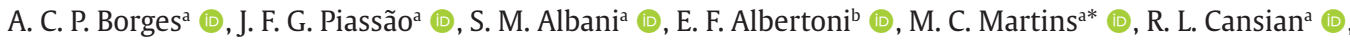 \\ A. T. Valduga ${ }^{a}$ (D) L. U. Hepp ${ }^{a}$ (D) and A. A. Mielniczki-Pereira ${ }^{a}$ (D) \\ aUniversidade Regional Integrada do Alto Uruguai e das Missões - URI, Departamento de Ciências Biológicas, Erechim, RS, Brasil \\ 'Universidade Federal do Rio Grande - FURG, Instituto de Ciências Biológicas, Rio Grande, RS, Brasil
}

\begin{abstract}
Metals and agrochemicals are among the main aquatic contaminants, being able to trigger oxidative stress in exposed organisms. The objective of this work was to evaluate the correlation between the level of oxidative stress biomarkers in Aegla crabs (Crustacea, Anomura) with (i) the set of metals present in the streams sediment and (ii) with land uses of three hydrographic basins. The study was carried out in streams ( $\leq 2$ nd order) of hydrographic basins in southern Brazil (Basins of Rio Suzana, Rio Ligeirinho-Leãozinho and Rio Dourado). In these streams were quantified the land uses and $\mathrm{Cu}, \mathrm{Cr}, \mathrm{Cd}, \mathrm{Fe}, \mathrm{Mn}$ and $\mathrm{Zn}$ concentrations in the sediment. The enzymes Catalase (CAT) and Glutathione Reductase (GR), as well as the level of membrane lipid peroxidation (TBARS), were analyzed in adult females. The PCA analysis showed that the distribution of metals was different between the basins. Cd, $\mathrm{Cr}$ and Fe were correlated positively with CAT and negatively with TBARS and GR. The Dourado basin had the lowest concentrations of these three metals and the highest levels of TBARS. However, in Dourado basin there is predominance of agriculture land use, and TBARS was positively correlated with agricultural land use. Besides in Dourado basin, GR activity was higher than in the others basins, indicating a compensatory response in relation to CAT inhibition. The basins of Suzana and Ligeirinho-Leãozinho rivers had lower TBARS values, which may be due to the induction of CAT in response to metals accumulated in sediment. In summary, this work indicates that in the basins with a higher concentration of toxic metals there is an adaptive response of CAT induction, which reduces TBARS in Aegla. On the other hand, in the basin with lower metallic contamination, TBARS occurrence was primarily influenced by agricultural land use.
\end{abstract}

Keywords: watershed, catalase, TBARS, gluthatione redutase, biomonitoring.

\begin{abstract}
Resumo
Os metais e agroquímicos estão entre os principais contaminantes aquáticos, podendo desencadear estresse oxidativo em organismos expostos. O objetivo deste trabalho foi avaliar uma possível correlação entre o nível de biomarcadores de estresse oxidativo em Aegla (Crustacea, Anomura) com (i) o conjunto de metais presentes no sedimento e (ii) com os usos da terra, em três bacias hidrográficas distintas. O estudo foi realizado em riachos $\left(\leq 2^{\mathrm{a}}\right.$ ordem) de bacias hidrográficas do Sul do Brasil (Bacias do Rio Suzana, do Rio Ligeirinho-Leãozinho e do Rio Dourado), as quais foram caracterizadas em função do percentual de usos da terra e do nível de $\mathrm{Cu}, \mathrm{Cr}, \mathrm{Cd}, \mathrm{Fe}$, Mn e Zn no sedimento. As enzimas Catalase (CAT) e Glutationa Redutase (GR), bem como o nível de peroxidação lipídica das membranas (TBARS), foram analisadas em fêmeas adultas. Uma análise de PCA mostrou que a distribuição de metais foi distinta entre as bacias. $\mathrm{Cd}, \mathrm{Cr}$ e Fe no sedimento correlacionaram positivamente com a CAT e negativamente com TBARS e GR. Entretanto, a bacia do Dourado apresentou os menores níveis destes três metais e os maiores níveis de TBARS, o que pode ser justificado pelo predomínio da agricultura nesta bacia, já que o TBARS correlacionou positivamente com o percentual de uso agrícola. Nesta bacia, a atividade da GR foi mais alta do que nas outras, indicando uma resposta compensatória em relação a inibição da CAT. As bacias do rio Suzana e rio Ligeirinho-Leãozinho apresentaram valores menores de TBARS, o que pode decorrer da indução da CAT em função dos metais acumulados no sedimento. Em síntese, este trabalho indica que nas bacias com maior concentração de metais tóxicos ocorre uma resposta adaptativa de indução da CAT, o que reduz os níveis de TBARS em Aegla. Por outro lado, na bacia com menor contaminação metálica os níveis de TBARS foram primariamente influenciados pelo uso agrícola.
\end{abstract}

Palavras-chave: bacia hidrográfica, catalase, TBARS, glutationa redutase, biomonitoramento.

*e-mail: monikcmartins@hotmail.com

Received: October 18, 2019 - Accepted: June 18, 2020 


\section{Introduction}

The combination of stressors as habitat and water flow alterations, sudden changes in physical-chemical parameters and, especially, contamination by metals and pesticides, have deleterious effects for many aquatic organisms and ecosystems (Romero, 2004; Magalhães et al., 2015). Metals are among the main aquatic contaminants, being common that a same aquatic environment to be contaminated by a range of different metals (La Colla et al., 2017; Qu et al., 2017).

Besides metals, agrochemicals and pesticides are also stressors frequently encountered as pollutants of surface water specially in cultivated areas (Moreno-González et al., 2013). Agricultural activity requires major changes in the environment for its development, including the removal of riparian forest and the intensive use of agrochemicals and fertilizers (Callisto et al., 2004; Campos, 2008). These chemical compounds can accumulate in the environment as well in the tissues of living organisms (Paulo and Serra, 2015).

The pattern of aquatic accumulation of metals and pesticides is influenced by human activities (Wang et al., 2016; Sundararajan et al., 2017) and land uses in the drainage areas (Bunzel et al., 2014). So, hydrographic basins are an important scale in the studies of environment impacts in aquatic habitats. Hydrographic basins with intensive agricultural land use are subjected to great inputs of pesticides (Moreno-González et al., 2013) and metals on water bodies (Naveedullah et al., 2013).

In this context, it is essential to understand how aforementioned pollutants interfere with the health of aquatic environments as well of the species that inhabit them, especially in basins affected by anthropogenic uses. Biomarkers are an excellent tool to assess effects of multiple stressors on living organisms (Damásio et al., 2011a; Colin et al., 2016), because they provide early warning signals at individual level to predict outcomes at population or community (Chapman et al., 2013).

Oxidative stress is one of the biological conditions that can be induced by exposure to metals (Kaur et al., 2014) and pesticides (Ndonwi et al., 2019). An organism in oxidative stress has impairment of redox homeostasis and use different defenses mechanisms to deal with this condition. The antioxidant defense can occur with help of the enzymes such as catalase (CAT), which is present in virtually all aerobic organisms (Halliwell and Gutteridge, 2007). Another important line of defense involves the glutathione system, within which enzyme Glutathione Reductase (GR) plays a key role in the recycling of reduced glutathione molecule (Halliwell and Gutteridge, 2007). If the antioxidant defense systems are not sufficiently efficient to cope with the stress, the body may be damaged at different cellular targets including oxidation of membrane lipids. This oxidation generates organic peroxides that can be detected by analysis of thiobarbituric acid reactive substances (TBARS) (Regoli and Winston, 1999). CAT, GR and TBARS are employed in environmental quality assessments because they are robust indicators with easy experimental evaluation (Damásio et al., 2008, 2011b). In addition, to being responsive to changes in land use and contamination by metals, pesticides and other pollutants (Damásio et al., 2011b).

In this work, freshwater crustaceans of Aegla genus Leach (1820) were used as bioindicadors for oxidative stress ecotoxicological analysis. Invertebrates of this genus are links in food chain (Bueno and Bond-Buckup, 2004; Cogo and Santos, 2013) as well are good models for in situ analyses of oxidative stress biomarkers (Borges et al., 2018). Thus, our objective was characterized three hydrographic basins in relation to the metals set in their sediments and in relation to the land uses, and so correlated these data with oxidative stress biomarkers in Aegla crabs. The main hypothesis of this work is that GR, CAT and TBARS, will response to the metals set and agricultural use at hydrographic basin scale.

\section{Material and Methods}

\subsection{Characterization of study area and sampling period}

The study was performed in 14 streams ( $\leq 2$ nd order) within 3 basins of Southern Brazil (Suzana River basin, Ligeirinho-Leãozinho River basin and Dourado River basin) (Figure 1). The climate belongs to category Cfb (Köppen), mean annual temperature is $17.6{ }^{\circ} \mathrm{C}$ and rainfall annual mean of $1912.3 \mathrm{~mm}$ (Alvares et al., 2013). The rainfall mean along the sampling period was about $151 \mathrm{~mm}$ (INMET, 2019) and the water temperature was $16.8 \pm 2.5^{\circ} \mathrm{C}$ (our data).

The rivers sampled inside each basin were characterized in relation to drainage area land uses. For this purpose, the perimeter of analyses was defined around the 2 streams (upstream and its respective downstream stretch) in the same main river, resulting in 7 sampling points (Figure 1 numbered boxes). The land uses classes were percentage of water blade, exposed soil, natural vegetation, agriculture, pasture and urbanized area, obtained with Mapinfo 8.5 software.

The sampling of biological material and sediment were carried out between March and June 2014 (fall season of south hemisphere). This period was defined to avoid the capture of juvenile crabs (Bueno and Bond-Buckup, 2004; Noro and Buckup, 2002). In all the cases, the sampling of Aegla and sediment from streams was made at same day.

\subsection{Metals analysis in sediment}

Concentrations of $\mathrm{Cu}$ (copper), $\mathrm{Cr}$ (chromium), Cd (cadmium), Fe (iron), Mn (manganese) and Zn (zinc) were analyzed in the potentially bioavailable fraction of the sediment. In each stream were collected three samples of sediment in the first $10 \mathrm{~cm}$ depth, using a sampler of $70 \mathrm{~mm}$ diameter. In the laboratory, they were dried at $45{ }^{\circ} \mathrm{C} / 24 \mathrm{~h}$ and sieved on sieve $\leq 62 \mu \mathrm{m}$ mesh. The resulting powder was diluted in $10 \mathrm{~mL}$ of $\mathrm{HCl} 0.1 \mathrm{~mol}$ $\mathrm{L}^{-1}\left(150 \mathrm{rpm}, 20^{\circ} \mathrm{C}, 12 \mathrm{~h}\right.$ ), filtered with $25 \mu \mathrm{m}$ filter and keep at $4{ }^{\circ} \mathrm{C}$ until analyses by flame atomic absorption spectrophotometry (Varian, SpectraAA55). For each metal, were generated standard curves used to calculate the metal concentration in the samples. The results are presented as mean \pm standard error. 

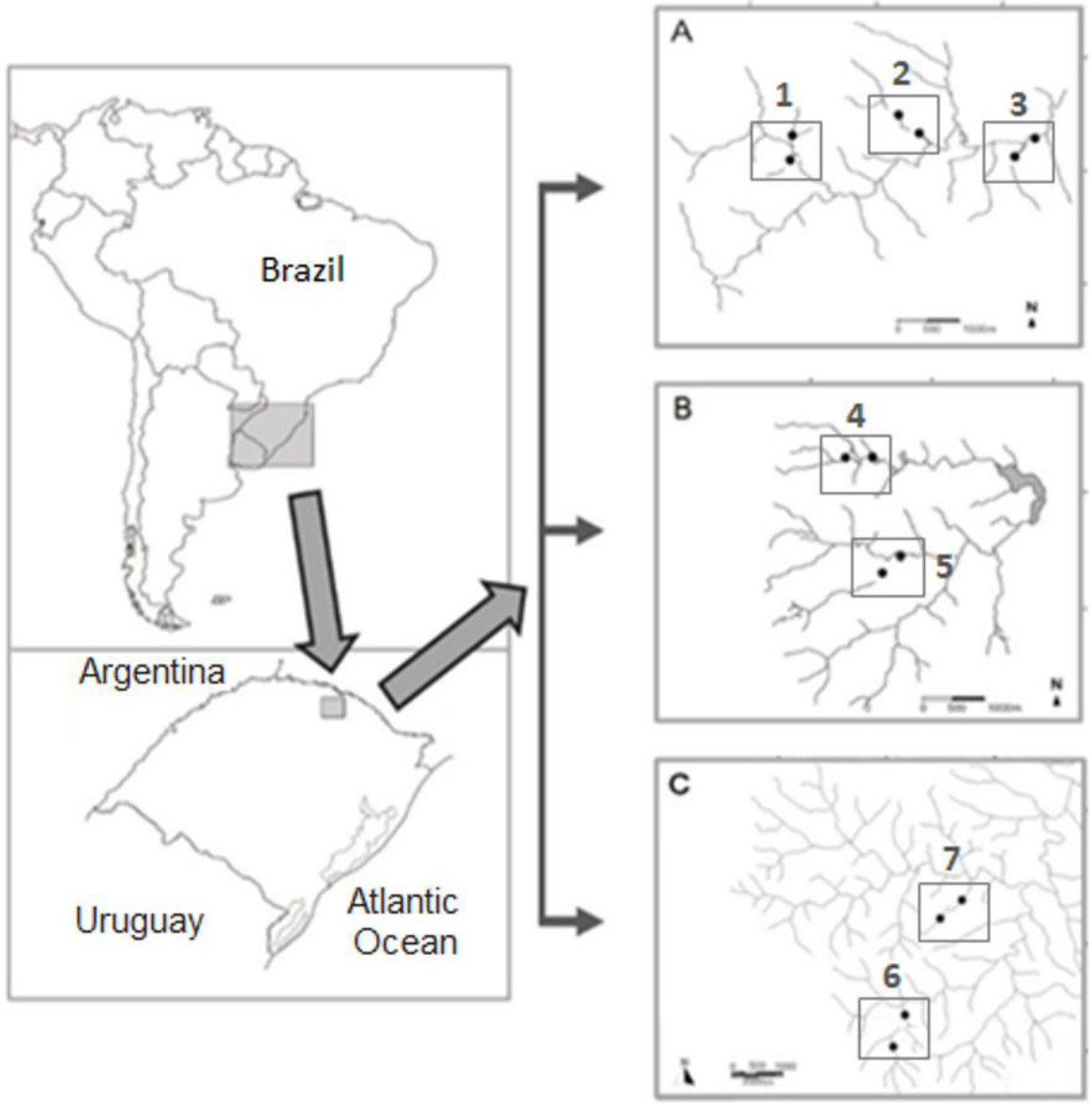

Figure 1. Map of the sampling sites. (A) Suzana River basin (between $27^{\circ} 35^{\prime} 38^{\prime \prime}$ and $27^{\circ} 36^{\prime} 16^{\prime \prime} \mathrm{S} ; 52^{\circ} 11^{\prime} 11^{\prime \prime}$ and $52^{\circ} 13^{\prime} 41^{\prime \prime} \mathrm{W}$ ); (B) Ligeirinho-Leãozinho River basin (between $27^{\circ} 40^{\prime} 15^{\prime \prime}$ and $27^{\circ} 36^{\prime} 16^{\prime \prime}$ ' ; 52 $2^{\circ} 16^{\prime} 03^{\prime \prime}$ and $52^{\circ} 13^{\prime} 41^{\prime \prime} \mathrm{W}$ ); (C) Dourado River basin (between $27^{\circ} 33^{\prime} 59^{\prime \prime}$ and $27^{\circ} 37^{\prime} 13^{\prime \prime} \mathrm{S} ; 52^{\circ} 17^{\prime} 46^{\prime \prime}$ and $52^{\circ} 19^{\prime} 36^{\prime \prime} \mathrm{W}$ ). The circles $\left(\bullet^{\circ}\right)$ indicate the sampled streams. The numbered boxes indicate the areas of land uses analysis.

\subsection{Organisms and biological extracts}

The crabs were collected using dip nets with a $30 \times 50 \mathrm{~cm}$ mouth, a depth $60 \mathrm{~cm}$ and $1.0 \mathrm{~mm}$ mesh. The study was made only with non ovigerous female of Aegla, all that being adults (with at least $15 \mathrm{~mm}$ carapace length). Females have no seasonal variation in oxidative stress biomarkers, in opposite to the observed in males (Borges et al., 2018). Sex and gender identification were done in field according to Melo (2003). Were collected 3 organisms per sampling site, totalizing 42 organisms ( 18 organisms from Suzana River basin; 12 from Ligeirinho-Leãozinho River basin; 12 from Dourado River basin). The organisms were kept inside of ice boxes and transported alive to the laboratory in flasks containing water from the own sampling site. The time interval between collection and arrival at the laboratory did not exceed 20 minutes. Once in the laboratory, each crab was used to the preparation of an individual biological extract (each crab considered as a sample unit) as described following. For the development of a robust assessment, in preparation of biological extracts we chose to use whole organisms, without separation of organs or tissues (except exoskeleton).

\subsection{Oxidative stress biomarkers analyses}

Biological extracts were obtained from individual crabs (Borges et al., 2018). Protein determination was assayed according to Bradford (1976). CAT (EC 1.11.1.6) activity was measured by rate of $\mathrm{H}_{2} \mathrm{O}_{2}$ degradation rate at $240 \mathrm{~nm}$ (Bertholdo-Vargas et al., 2009) and was expressed in international units (U), which is defined as the amount of enzyme that catalyzes the degradation of $1 \mu \mathrm{mol} \mathrm{H} \mathrm{O}_{2} \mathrm{~min}^{-1} \mathrm{mg}^{-1}$ protein. GR (EC 1.6.4.2) activity was measured following NADPH consumption at $340 \mathrm{~nm}$ (Ramos-Vasconcelos and Hermes-Lima, 2003). Were performed kinetic reactions of 6 minutes, with data acquisition at each 30 seconds, being that in the first 3 minutes was made the reading of blank (buffer, NADPH and biological samples) and then the reaction was initiated by GSSG addition. GR activity was expressed in international units (U), defined as the amount of enzyme that catalyzes the consumption of $1 \mu \mathrm{mol}$ NADPH min $^{-1} \mathrm{mg}^{-1}$ protein. TBARS levels were quantified in according to Esterbauer and Cheeseman (1990) and were expressed as nmol MDA mg-1 protein. The data are presenting as mean \pm standard error. Biochemical analyses 
were performed at least in triplicate. Biomarkers general means were obtained from the average of replications of each individual organism (each crab was considering one sample unit).

\subsection{Data analysis}

The normality of data was tested by AndersonDarling test. Only TBARS not fit in normal curve and was then normalized by logarithmic conversion using box-cox approach. The metal content in sediment as well biomarkers in Aegla between three basins were compared by one way ANOVA and Tukey post hoc test. A principal component analysis (PCA) was performed to evaluate the metal distribution in sediment of the three basins. The metal sediment matrix was standardized in 0 - 1 values using the 'range' function of "vegan" package (Oksanen et al., 2010). This standardization considers the maximum values within each data set variables. Pearson correlation test was used to analyze the correlation between the metal concentration and biomarker levels, and Spearman correlation was employed to analyze the correlation between biomarkers and land uses. The analyses were performed using "vegan" package (Oksanen et al., 2010) software R (R Development Core Team, 2010) and $\mathrm{p}<0.05$ were considered statistically significant.

\section{Results}

\subsection{Hydrographic basins land uses}

The rivers of all basins studied presented high percentage of anthropogenic land uses, with lower value observed inside Suzana River basin (58.8\%) and the upper value on Ligeirinho-Leãozinho basin (87.5\%) (Table 1). In these two basins, the main anthropogenic influence was exposed soil, while agriculture and pasture predominates in Dourado River basin.

\subsection{Metal concentration in sediment}

Metal content varied between the hydrographic basins (Table 2). Dourado River basin presented the lower concentrations of $\mathrm{Cd}, \mathrm{Cr}$, Fe and the highest level of $\mathrm{Mn}$, distinguished itself from the two other basins. Suzana River basin and Ligeirinho-Leãozinho River basin presented similar metal composition in the sediment, except for Fe and $\mathrm{Zn}$ (Table 2). In agreement, PCA also showed that metals were distributed in relation to hydrographic basin. The first two principal components (PC) explained $70 \%$ of the variation, with PC1 explained $48.5 \%$ and PC2 explained $21.5 \%$ of data variation (Figure 2). For Dourado River basin, Mn concentration ordered the study sites. In Ligeirinho-Leãozinho River basin, the main ordination factor was $\mathrm{Zn}$ concentration. For Suzana River basin, the concentration of $\mathrm{Fe}, \mathrm{Cr}$ and $\mathrm{Cd}$ ordered studied sites and presented partial superposition with the Ligeirinho-Leãozinho River basin (Figure 2).

\subsection{Oxidative stress biomarkers}

TBARS, CAT and GR showed variation between the studied hydrographic basins (Figure 3). CAT and TBARS had a significant negative correlation at basin scale $(r=-0.98$, $\mathrm{p}=0.039$ ). TBARS levels was approximately $60 \%$ higher in the organisms from Dourado River basin as compared to Suzana River basin ( 0.75 and $0.47 \mathrm{nmol} \mathrm{MDA} \mathrm{mg}^{-1}$ protein, respectivelly). CAT showed opposite pattern, highest enzymatic activity was observed in organisms from Suzana River basin (11.48 U), whereas lower enzymatic activity occurred in organisms from Dourado River basin (7.27 U) (Figure 3). GR activity was also higher in Dourado river basin (72.6 U), reaching values $28 \%$ and $53 \%$ upper in relation to Ligeirinho-Leãozinho and Suzana Rivers basins (56.76 and $47.34 \mathrm{U}$ ), respectively. However, GR activity no have significant correlation with the two other biomarkers.

\subsection{Metal concentration, land uses and oxidative stress biomarkers}

Several analyzed metals showed correlation with studied biomarkers (Table 3). CAT presented positive

Table 1. Characterization of hydrographic basins land uses (\%).

\begin{tabular}{|c|c|c|c|c|c|c|c|c|}
\hline Basin & 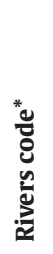 & $\frac{\grave{d}}{3}$ & 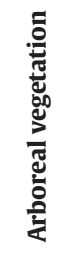 & 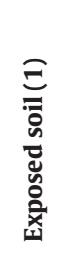 & 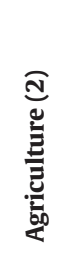 & 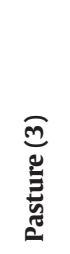 & 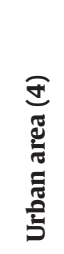 & 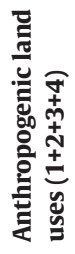 \\
\hline \multirow[t]{3}{*}{ Suzana basin } & 1 & 0.4 & 21.5 & 32.8 & 17.2 & 28.1 & 0.0 & 78.1 \\
\hline & 2 & 0.0 & 41.2 & 27.2 & 10.9 & 20.7 & 0.0 & 58.8 \\
\hline & 3 & 0.4 & 25.7 & 30.9 & 18.9 & 19.4 & 4.7 & 73.9 \\
\hline \multirow[t]{2}{*}{ Ligeirinho-Leãozinho basin } & 4 & 0.0 & 19.0 & 32.5 & 14.9 & 19.7 & 14.0 & 81.0 \\
\hline & 5 & 0.1 & 12.4 & 43.3 & 31.3 & 12.9 & 0.0 & 87.5 \\
\hline \multirow[t]{2}{*}{ Dourado basin } & 6 & 0.0 & 40.4 & 14.3 & 19.1 & 23.5 & 2.7 & 59.6 \\
\hline & 7 & 0.0 & 29.8 & 18.9 & 28.9 & 22.4 & 0.0 & 70.2 \\
\hline
\end{tabular}

*In accordance with Figure 1. 
Table 2. Mean \pm standard error of metal concentration in bioavailable fraction of the sediment in the studied hydrographic basins (Suzana River basin, Ligeirinho-Leãozinho River basin, Dourado River basin).

\begin{tabular}{|c|c|c|c|}
\hline \multirow{2}{*}{ Metals $\left(\mu \mathrm{g} . \mathrm{g}^{-1}\right)^{*}$} & \multicolumn{3}{|c|}{ Hydrographic Basins } \\
\hline & Suzana & Ligeirinho- Leãozinho & Dourado \\
\hline $\mathrm{Cd}$ & $0.038 \pm 0.001^{\mathrm{a}}$ & $0.036 \pm 0.002^{\mathrm{a}}$ & $0.027 \pm 0.001$ \\
\hline $\mathrm{Cu}$ & $0.568 \pm 0.021^{\mathrm{a}}$ & $0.642 \pm 0.046^{\mathrm{a}}$ & $0.582 \pm 0.009$ a \\
\hline $\mathrm{Cr}$ & $0.250 \pm 0.010^{a}$ & $0.288 \pm 0.046^{\mathrm{a}}$ & $0.004 \pm 0.002^{b}$ \\
\hline $\mathrm{Fe}$ & $2.049 \pm 0.187^{a}$ & $1.455 \pm 0.117^{\mathrm{b}}$ & $0.710 \pm 0.042^{c}$ \\
\hline Mn & $1.520 \pm 0.168^{a}$ & $1.503 \pm 0.286^{\mathrm{a}}$ & $2.510 \pm 0.105^{b}$ \\
\hline $\mathrm{Zn}$ & $0.410 \pm 0.028^{a}$ & $0.708 \pm 0.122^{b}$ & $0.614 \pm 0.115^{b}$ \\
\hline
\end{tabular}

*Different letters indicate statistical differences $(\mathrm{p}<0.05)$ between the basins for each metal individually.

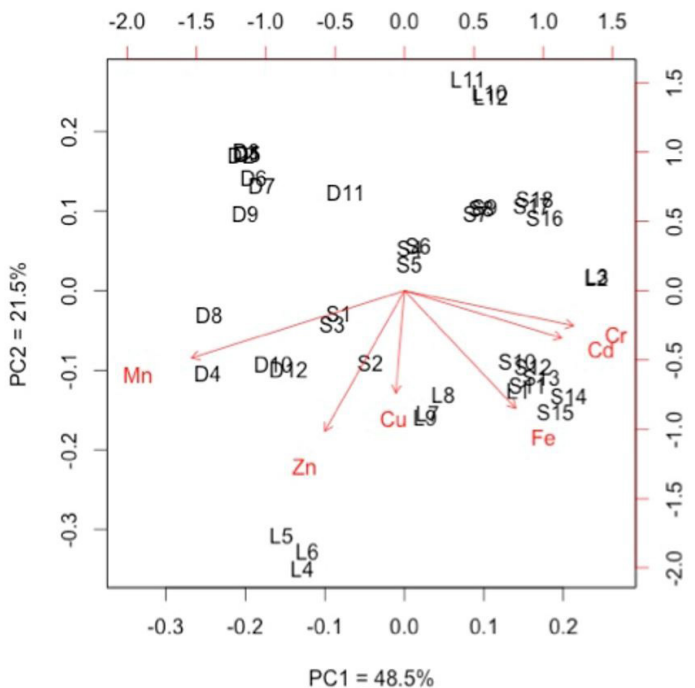

Figure 2. Biplot of PCA ordination for the metal concentration in sediment of the three studied basins. Suzana River basin (S); Ligeirinho-Leãozinho River basin (L); Dourado River basin (D).

correlation with $\mathrm{Cd}, \mathrm{Cr}$ and $\mathrm{Fe}$, while was negatively related to $\mathrm{Mn}$ concentration. The concentrations of $\mathrm{Cd}$, $\mathrm{Cr}$ and $\mathrm{Fe}$ in sediment were also correlated to TBARS and GR biomarkers; however, in these cases the correlations were negative. In relation to the land uses, TBARS was correlated positively with agricultural land use. The remain land uses no presented any significant correlation with biomarkers (Table 4).

\section{Discussion}

In this work, we quantify the concentrations of metals in stream sediments in three watersheds and evaluate the relationship with oxidative stress biomarkers in Aegla crabs. We observed that the relationships between metals and biomarkers were different and that agricultural use was related to oxidative stress (TBARS) of studied organisms.

Metals are common elements on lotic environments in which the metals variety and magnitude will dependent to the natural sources and contamination by external inputs
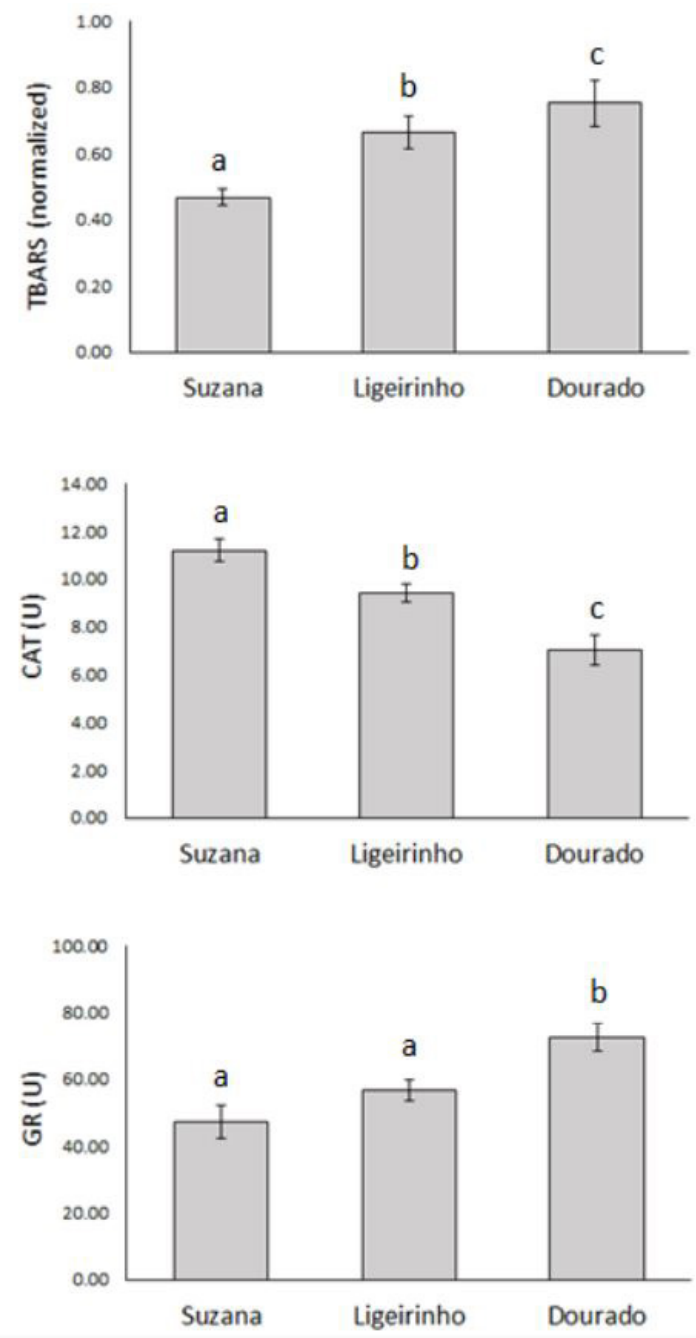

Figure 3. Biomarkers grouped by hydrographic basin (Suzana River basin, Ligeirinho-Leãozinho River basin, Dourado River basin). Different letters indicate significant differences ( $p<0.05$ ), as compared by one-way ANOVA plus Tukey post-test (between basins).

as well of land uses (Thévenot et al., 2007; Proshad et al., 2019). In this study, the three analyzed hydrographic basins presented singularities related to the set of metal in their 
Table 3. Correlation ( $\mathrm{r}$ ) between sediment metal concentration and oxidative stress biomarkers (TBARS, CAT and GR).

\begin{tabular}{|c|c|c|c|c|c|c|}
\hline \multirow{2}{*}{ Metals } & \multicolumn{2}{|c|}{ CAT } & \multicolumn{2}{|c|}{ TBARS } & \multicolumn{2}{|c|}{ GR } \\
\hline & $\mathbf{R}$ & $\mathbf{P}$ & $\mathbf{r}$ & $\mathbf{p}$ & $\mathbf{r}$ & $\mathbf{p}$ \\
\hline $\mathrm{Cd}$ & 0.58 & $<0.001^{*}$ & -0.40 & $0.012^{*}$ & -0.40 & $0.011^{*}$ \\
\hline $\mathrm{Cu}$ & -0.16 & 0.311 & 0.20 & 0.202 & -0.29 & 0.069 \\
\hline $\mathrm{Cr}$ & 0.63 & $<0.001^{*}$ & -0.47 & $0.002^{*}$ & -0.38 & $0.018^{*}$ \\
\hline $\mathrm{Fe}$ & 0.50 & $<0.001^{*}$ & -0.41 & $0.009^{*}$ & -0.51 & $0.001^{*}$ \\
\hline Mn & -0.39 & $0.013^{*}$ & 0.13 & 0.413 & 0.21 & 0.194 \\
\hline $\mathrm{Zn}$ & -0.26 & 0.089 & 0.11 & 0.481 & 0.11 & 0.493 \\
\hline
\end{tabular}

*Indicates significant correlation $(\mathrm{p}<0.05)$.

Table 4. Correlation (r) land uses percentage and oxidative stress biomarkers (TBARS, CAT and GR).

\begin{tabular}{|c|c|c|c|c|c|c|}
\hline \multirow{2}{*}{ Land uses } & \multicolumn{2}{|c|}{ CAT } & \multicolumn{2}{|c|}{ TBARS } & \multicolumn{2}{|c|}{ GR } \\
\hline & $\mathbf{r}$ & $\mathbf{P}$ & $\mathbf{r}$ & $\mathbf{p}$ & $\mathbf{r}$ & $\mathbf{p}$ \\
\hline Tree vegetation & -0.29 & 0.498 & -0.50 & 0.267 & 0.57 & 0.167 \\
\hline Exposed soil & -0.14 & 0.713 & 0.64 & 0.110 & -0.54 & 0.236 \\
\hline Agriculture & 0.86 & $0.012^{*}$ & -0.32 & 0.444 & 0.21 & 0.595 \\
\hline Pasture & -0.18 & 0.713 & -0.29 & 0.498 & 0.36 & 0.444 \\
\hline Urban area & -0.04 & 0.952 & 0.39 & 0.381 & -0.67 & 0.124 \\
\hline
\end{tabular}

${ }^{*}$ Indicates significant correlation $(\mathrm{p}<0.05)$.

sediments. This result reflects the diffuse nature of water contaminations in rural areas (Turunen et al., 2019), which are affected by variables as uncontrolled management of fertilizers (Smith and Siciliano, 2015), rainfall rate (Schulz, 2001), soil erosion (Thévenot et al., 2007) and topography of the watershed (Ye et al., 2009).

The concentration of several metals at the rivers sediment showed correlation with the levels of oxidative stress biomarkers in Aegla. Sediments are sites for longterm metals storage and consequently their profile is an important indicator of environmental quality ( $Q u$ et al., 2017). Metals in sediments are able to bioaccumulate in aquatic organisms and this process is influenced by the feeding strategy and agricultural activity around streams (Loureiro et al., 2018). Aegla crab is a filter macroinvertebrate and feeds on lower invertebrates and leaf debris (Cogo and Santos, 2013), which facilities the access to sediment content. The bioaccumulation of Cd in Aegla is negatively correlated with the $\mathrm{Cd}$ presence in the stream sediments (Piassão et al., 2019) which could suggest an easily of this metal transfer into the crab body.

The Dourado River basin was the most differentiated in terms of metal composition, showing the lower levels of $\mathrm{Cd}, \mathrm{Cr}$ and $\mathrm{Fe}$. Those last are metals with high potential to generate oxidative stress (Valko et al., 2005), so it's surprising that samples of Aegla from Dourado River basin had presented the highest values of TBARS. On the other hand, the Dourado River basin has a predominance of agricultural land use. This is related to the increase in lipid peroxidation in Aegla, since the TBARS showed a strong correlation with agriculture in the river basins. Agriculture is an important economic activity in the study region, with crop rotation during the year (Rovani et al., 2020), which promotes a continuous use of agrochemicals and pesticides (Lima et al., 2020). These latter can contaminate water bodies by spraying, leaching, erosion processes, among others (Peters et al., 2013). Beside metals, several pesticides also have a strong ability to generate oxidative stress and, in particular, increasing lipid peroxidation (Clasen et al., 2018; Ndonwi et al., 2019).

Reduction of CAT activity can occur by in vivo exposure to pesticides and herbicides (Toni et al., 2010; Ndonwi et al., 2019). In the present work, the lower levels of CAT were measured in organism from Dourado River basin, in which agricultural activity was predominant. Besides, our data showed an inverse correlation between TBARS and CAT activity in Aegla. So, it is possible infer that agricultural land uses, and consequently, their contaminants, could be inhibiting CAT in Aegla from Dourado River basin. As a consequence of this, there may be a favoring of lipid peroxidation in these organisms. The inverse profile of CAT and lipid peroxidation in response to agrochemicals was described for Eriocheir sinensis crab exposed to subletal concentrations of avermectin (Huang et al., 2019) and to synthetic pyrethroid deltamethrin (Hong et al., 2019). The increased GR activity in Dourado River basin can represents a response of the Aegla to cope with stress using defenses linked to the glutathione antioxidant system, as well for xenobiotics detoxification by Gluthatione-S-Transferase. This behavior has already been observed in crabs exposed to pesticides avermectin, trichlorphon and $\beta$-cypermethrin (Zhang et al., 2020).

The three analyzed biomarkers were correlate with a common group of metals ( $\mathrm{Cd}, \mathrm{Cr}$ and $\mathrm{Fe}$ ). CAT activity can be influenced differently depending on the nature and magnitude of contact with metallic elements. For example, 
Cd is known for its ability to inhibit catalase in vivo and in vitro (Wang et al., 2015). However, in Sinopotamon henanense freshwater crab, the treatment with $\mathrm{Cd}$ can both stimulates or inhibit CAT, depending on the concentration (Wu et al., 2013). In Tubifex tubifex (a freshwater worm) the simultaneous treatment with $\mathrm{Cd}$ and Fe increase CAT in vivo, being that certain concentrations of Fe appears to protect against $\mathrm{Cd}$ toxicity (Chen et al., 1994). $\mathrm{Cr}$ are also associated with increase of CAT activity in vivo (Elia et al., 2007). Our results indicated that $\mathrm{Cd}$, $\mathrm{Cr}$ and $\mathrm{Fe}$ concentrations in sediment of the Suzana and LigeirinhoLeãozinho Rivers basins, having the effect of CAT induction and, consequently, containing the lipid peroxidation in Aegla from these hydrographic basins.

In summary, this work showed that both agriculture land use and the concentration of metals in sediments affect oxidative biomarkers in Aegla. Basins with higher content of poisoning metals leads to an adaptive response mediate by increase in CAT activity, which reduces TBARS levels. On the other hand, the hydrographic basin with minor metals contamination (Dourado River basin) was primarily influenced by the agricultural land use. In these case, the agrochemicals toxicity overcomes the effect of metals, resulting in CAT inhibition and adjustment of GR levels, which does not seem to be enough to contain oxidative stress, as TBARS levels remain high.

\section{Acknowledgements}

The authors thank National Council for Scientific and Technological Development - CNPq (Grants n. 473648/2013-0), Foundation for Research Support of the State of Rio Grande do Sul - FAPERGS, all them from Brazil, for financial support. This study was financed in part by the Coordenação de Aperfeiçoamento de Pessoal de Nível Superior - Brasil (CAPES). LUH receives CNPq (421632/2016-0) and CNPq grants (305203/2017-7).

\section{References}

ALVARES, C.A., STAPE, J.L., SENTELHAS, P.C., GONÇALVES, J.L. and SPAROVEK, G., 2013. Köppen's climate classification map for Brazil. Meteorologische Zeitschrift, vol. 22, no. 6, pp. 711-728. http://dx.doi.org/10.1127/0941-2948/2013/0507.

BERTHOLDO-VARGAS, L.R., MARTINS, J.N., BORDIN, D., SALVADOR, M., SCHAFER, A.L., BARROS, N.M., BARBIERI, L., STIRPE, F. and CARLINI, C.R., 2009. Type 1 ribosome-inactivating proteins - Entomotoxic, oxidative and genotoxic action on Anticarsia gemmatalis (Hubner) and Spodoptera frugiperda (J.E. Smith) (Lepidoptera: noctuidae).Journal of Insect Physiology, vol. 55, no. 1, pp. 51-58. http://dx.doi.org/10.1016/j.jinsphys.2008.10.004. PMid: 19000694

BORGES, A.C.P., PIASSÃO, J.F.G., PAULA, M.O., SEPP, S., BEZ, C.F.S., HEPP, L.U., VALDUGA, A.T., PEREIRA, A.A.M. and CANSIAN, R.L., 2018. Characterization of oxidative stress biomarkers in a freshwater anomuran crab. Brazilian Journal of Biology = Revista Brasileira de Biologia, vol. 78, no. 1, pp. 61-67. http://dx.doi. org/10.1590/1519-6984.04816. PMid:28614422.

BRADFORD, M.M., 1976. A rapid and sensitive method for the quantitation of microgram quantities of protein utilizing the principle of protein-dye binding. Analytical Biochemistry, vol. 72, no. 1-2, pp. 248-254. http://dx.doi.org/10.1016/00032697(76)90527-3. PMid:942051.

BUENO, A.A.P. and BOND-BUCKUP, G., 2004. Natural diet of Aegla platensis Schmitt and Aegla ligulata. Acta Limnologica Brasiliensia, vol. 16, pp. 115-127.

BUNZEL, K., LIESS, M. and KATTWINKEL, M., 2014. Landscape parameters driving aquatic pesticide exposure and effects. Environmental Pollution, vol. 186, pp. 90-97. http://dx.doi. org/10.1016/j.envpol.2013.11.021. PMid:24365537.

CALLISTO, M. and GONÇALVES JÚNIOR, J.F. and MORENO, P., 2004. Invertebrados aquáticos como bioindicadores. In: E.M.A. GOULART, ed. Navegando o Rio das Velhas das Minas aos Gerais. Belo Horizonte: UFMG, pp. 1-12.

CAMPOS, V.D., 2008. Dinâmica de uso e ocupação da terra na bacia hidrográfica do Arroio dos Pereiras em Irati - PR e sua influência na qualidade das águas superficiais. Ponta Grossa: Universidade Estadual de Ponta Grossa, 112 p. Dissertação de Mestrado em Gestão do Território.

CHAPMAN, P.M., WANG, F. and CAEIRO, S.S., 2013. Assessing and managing sediment contamination in transitional waters. Environment International, vol. 55, pp. 71-91. http://dx.doi. org/10.1016/j.envint.2013.02.009. PMid:23528483.

CHEN, T., FURST, A. and CHIEN, P.K., 1994. The effects of cadmium and iron on catalase activities in tubifex. International Journal of Toxicology, vol. 13, no. 2, pp. 112-120. http://dx.doi. org/10.3109/10915819409140992.

CLASEN, B., LORO, V.L., MURUSSI, C.R., TIECHER, T.L., MORAES, B. and ZANELLA, R., 2018. Bioaccumulation and oxidative stress caused by pesticides in Cyprinus carpio reared in a rice-fish system. The Science of the Total Environment, vol. 626, pp. 737-743. http:// dx.doi.org/10.1016/j.scitotenv.2018.01.154. PMid:29358144.

COGO, G.B. and SANTOS, S., 2013. The role of aeglids in shredding organic matter in Neotropical streams. Journal of Crustacean Biology, vol. 33, no. 4, pp. 519-526. http://dx.doi. org/10.1163/1937240X-00002165.

COLIN, N., PORTE, C., FERNANDES, D., BARATA, C., PADRÓS, F., CARRASSÓN, M., MONROY, M., CANO-ROCABAYERA, O., SOSTOA, A., PIÑA, B. and MACEDA-VEIGA, A., 2016. Ecological relevance of biomarkers in monitoring studies of macro-invertebrates and fish in Mediterranean rivers. The Science of the Total Environment, vol.540, pp. 307-323. http://dx.doi.org/10.1016/j. scitotenv.2015.06.099. PMid:26148426.

DAMÁSIO, J., BARCELÓ, D., BRIX, R., POSTIGO, C., GROS, M., PETROVIC, M., SABATER, S., GUASCH, H., DE ALDA, M.L. and BARATA, C., 2011a. Are pharmaceuticals more harmful than other pollutants to aquatic invertebrate species: a hypothesis tested using multi-biomarker and multi-species responses in field collected and transplanted organisms. Chemosphere, vol. 85, no. 10, pp. 1548-1554. http://dx.doi.org/10.1016/j. chemosphere.2011.07.058. PMid:21925701.

DAMÁSIO, J., FERNÁNDEZ-SANJUAN, M., SÁNCHEZ-AVILA, J., LACORTE, S., PRAT, N., RIERADEVALL, M., SOARES, A.M.V.M. and BARATA, C., 2011b. Multi-biochemical responses of benthic macroinvertebrate species as a complementary tool to diagnose the cause of community impairment in polluted rivers. Water Research, vol. 45, no. 12, pp. 3599-3613. http:// dx.doi.org/10.1016/j.watres.2011.04.006. PMid:21571352.

DAMÁSIO, J., TAULER, R., TEIXIDÓ, E., RIERADEVALL, M., PRAT, N., RIVA, M.C., SOARES, A.M. and BARATA, C., 2008. Combined use of Daphnia magna in situ bioassays, biomarkers and biological indices to diagnose and identify environmental pressures on invertebrate communities in two Mediterranean urbanized and 
industrialized rivers (NE Spain). Aquatic Toxicology, vol. 87, no. 4, pp. 310-320. http://dx.doi.org/10.1016/j.aquatox.2008.02.016. PMid: 18420289 .

ELIA, A.C., GALARINI, R., MARTIN DÖRR, A.J. and TATICCHI, M.I., 2007. Heavy metal contamination and antioxidant response of a freshwater bryozoan (Lophopus crystallinus Pall., Phylactolaemata). Ecotoxicology and Environmental Safety, vol. 66, no. 2, pp. 188-194. http://dx.doi.org/10.1016/j. ecoenv.2005.12.004. PMid:16469378.

ESTERBAUER, H. and CHEESEMAN, K.H., 1990. Determination of aldehydic lipid peroxidation products: malonaldehyde and 4-hydroxynonenal. Methods in Enzymology, vol. 186, pp. 407-421. http://dx.doi.org/10.1016/0076-6879(90)86134-H. PMid:2233308.

HALLIWELL, B. and GUTTERIDGE, J.M.C., 2007. Free radicals in biology and medicine. 4th ed. New York: Oxford University Press.

HONG, Y., HUANG, Y., YAN, G. and HUANG, Z., 2019. Effects of deltamethrin on the antioxidant defense and heat shock protein expression in Chinese mitten crab, Eriocheir sinensis. Environmental Toxicology and Pharmacology, vol. 66, pp. 1-6. http://dx.doi.org/10.1016/j.etap.2018.12.012. PMid:30584970.

HUANG, Y., HONG, Y., HUANG, Z., ZHANG, J. and HUANG, Q., 2019. Avermectin induces the oxidative stress, genotoxicity, and immunological responses in the Chinese Mitten Crab, Eriocheir sinensis. PLoS One, vol. 14, no. 11, pp. e0225171. http://dx.doi. org/10.1371/journal.pone.0225171. PMid:31765405.

INSTITUTO NACIONAL DE METEREOLOGIA - INMET, 2019 [viewed 2 May 2020]. Boletins climáticos para o Rio Grande do Sul: ano 2019 [online]. Available from: http://www.inmet.gov.br/portal/ index.php?r=clima/boletimRioGrandeDoSul

KAUR, R., KAUR, J., MAHAJAN, J., KUMAR, R. and ARORA, S., 2014. Oxidative stress-implications, source and its prevention. Environmental Science and Pollution Research International, vol. 21, no. 3, pp. 1599-1613. http://dx.doi.org/10.1007/s11356-0132251-3. PMid:24170504.

LA COLLA, N.S., BOTTÉ, S.E., OLIVA, A.L. and MARCOVECCHIO, J.E., 2017. Tracing $\mathrm{Cr}, \mathrm{Pb}, \mathrm{Fe}$ and $\mathrm{Mn}$ occurrence in the Bahía Blanca estuary through commercial fish species. Chemosphere, vol. 175, pp. 286-293. http://dx.doi.org/10.1016/j. chemosphere.2017.02.002. PMid:28232139.

LIMA, J.A.M.C., LABANOWSKI, J., BASTOS, M.C., ZANELLA, R., PRESTES, O.D., VARGAS, J.P.R., MONDAMERT, L., GRANADO, E., TIECHER, T., ZAFAR, M., TROJAN, A., LE GUET, T. and SANTOS, D.R., 2020. "Modern agriculture" transfers many pesticides to watercourses: a case study of a representative rural catchment of southern Brazil. Environmental Science and Pollution Research International, vol. 27, no. 10, pp. 10581-10598. http://dx.doi. org/10.1007/s11356-019-06550-8. PMid:31942716.

LOUREIRO, R.C., MENEGAT, M., RESTELLO, R.M. and HEPP, L.U., 2018. Incorporation of zinc and copper by insects of different functional feeding groups in agricultural streams. Environmental Science and Pollution Research International, vol. 25, no. 18, pp. 17402-17408. http://dx.doi.org/10.1007/s11356-018-1971-9. PMid:29654465.

MAGALHÃES, D.P., MARQUES, M.R.C., BAPTISTA, D.F. and BUSS, D.F., 2015. Metal bioavaliability and toxicity in freshwaters. Environmental Chemistry Letters, vol. 13, no. 1, pp. 69-87. http:// dx.doi.org/10.1007/s10311-015-0491-9.

MELO, G.A.S., 2003. Manual de identificação dos Crustacea Decapoda de água doce do Brasil. São Paulo: Edições Loyola.

MORENO-GONZÁLEZ, R., CAMPILLO, J.A. and LEÓN, V.M., 2013. Influence of an intensive agricultural drainage basin on the seasonal distribution of organic pollutants in seawater from a Mediterranean coastal lagoon (Mar Menor, SE Spain). Marine Pollution Bulletin, vol. 77, no. 1-2, pp. 400-411. http://dx.doi. org/10.1016/j.marpolbul.2013.09.040. PMid:24139646.

NAVEEDULLAH., HASHMI, M.Z., YU, C., SHEN, H., DUAN, D., SHEN, C., LOU, L. and CHEN, Y., 2013. Risk Assessment of Heavy Metals Pollution in Agricultural Soils of Siling Reservoir Watershed in Zhejiang Province, China. BioMed Research International, vol. 2013, pp. 590306. http://dx.doi.org/10.1155/2013/590306. PMid:24151611.

NDONWI, E.N., ATOGHO-TIEDEU, B., LONTCHI-YIMAGOU, E., SHINKAFI, T.S., NANFA, D., BALTI, E.V., INDUSMITA, R., MAHMOOD, A., KATTE, J.-C., ARMMBANYA., MATSHA, T., MBANYA, J.C., SHAKIR, A. and SOBNGWI, E., 2019. Gestational exposure to pesticides induces oxidative stress and lipid peroxidation in offspring that persist at adult age in an animal model. Toxicological Research, vol. 35, no. 3, pp. 241-248. http:// dx.doi.org/10.5487/TR.2019.35.3.241. PMid:31341553.

NORO, C.K. and BUCKUP, L., 2002. Biologia reprodutiva e ecologia de Aegla leptoaectyla Buckup \& Rossi (Crustacea, Anomura, Aeglidae). Revista Brasileira de Zoologia, vol. 19, no. 4, pp. 10631079. http://dx.doi.org/10.1590/S0101-81752002000400011.

OKSANEN, J., BLANCHET, F.G., KINDT, R., LEGENDRE, P., O'HARA, R.B., SIMPSON, G.L., SOLYMOS, P., STEVENS, M.H.H. and WAGNER, H. 2010 [viewed 2 May 2020]. Multivariate analysis of ecological communities [online]. Vienna: R Foundation for Statistical Computing. Available from: https://vegan.r-forge.r-project.org/

PAULO, R.L. and SERRA, J.C.V., 2015. Estudo de caso envolvendo uma indústria de fertilizantes na cidade de Porto Nacional/ TO. Sistemas E' Gestão, vol. 10, no. 2, pp. 316-323. http://dx.doi. org/10.7177/sg.2015.v10.n2.a8.

PETERS, K., BUNDSCHUH, M. and SCHÄFER, R.B., 2013. Review on the effects of toxicants on freshwater ecosystem functions. Environmental Pollution, vol. 180, pp. 324-329. http://dx.doi. org/10.1016/j.envpol.2013.05.025. PMid:23725857.

PIASSÃO, J.F.G., GASPARIN, B.G., MARTINS, M.C., DECIAN, V.S., CANSIAN, R.L., RESTELLO, R.M. and MIELNICZKI-PEREIRA, A.A., 2019. Analysis of metals bioaccumulation and oxidative stress biomarkers in crustaceans of Aegla genus (Crustacea, Anomura). Perspectiva, vol. 43, no. 161, pp. 111-122.

PROSHAD, R., KORMOKER, T. and ISLAM, S., 2019. Distribution, source identification, ecological and health risks of heavy metals in surface sediments of the Rupsa River, Bangladesh. Toxin Reviews, pp. 1-25. http://dx.doi.org/10.1080/15569543. 2018.1564143.

QU, X., REN, Z., ZHANG, M., LIU, X. and PENG, W., 2017. Sediment heavy metals and benthic diversities in Hun-Tai River, northeast of China. Environmental Science and Pollution Research International, vol. 24, no. 11, pp. 10662-10673. http://dx.doi. org/10.1007/s11356-017-8642-0. PMid:28283976.

R DEVELOPMENT CORE TEAM, 2010. R: a language and environment for statistical computing. Vienna: R Foundation for Statistical Computing. Available from: http://www.R-project.org

RAMOS-VASCONCELOS, G.R. and HERMES-LIMA, M., 2003. Hypometabolism, antioxidant defenses and free radical metabolism in the pulmonate land snail Helix aspersa. The Journal of Experimental Biology, vol. 206, no. Pt 4, pp. 675-685. http://dx.doi.org/10.1242/jeb.00124. PMid:12517985.

REGOLI, F. and WINSTON, G.W., 1999. Quantification of total oxidant scavenging capacity of antioxidants for peroxynitrite, peroxyl radicals, and hydroxyl radicals. Toxicology and Applied Pharmacology, vol. 156, no. 2, pp. 96-105. http://dx.doi. org/10.1006/taap.1999.8637. PMid:10198274. 
ROMERO, L.M., 2004. Physiological stress in ecology: lessons from biomedical research. Trends in Ecology \& Evolution, vol. 19, no. 5, pp. 249-255. http://dx.doi.org/10.1016/j.tree.2004.03.008. PMid:16701264

ROVANI, I.L., DECIAN, V.S., ZANIN, E.M., BRANDALISE, M., QUADROS, F.R. and HEPP, L.H., 2020. Socioeconomic changes and land use and land cover of the Northern Region of Rio Grande do Sul, Brazil. Floresta e Ambiente, vol. 27, no. 3, e20180258. http:// dx.doi.org/10.1590/2179-8087.025818.

SCHULZ, R., 2001. Rainfall-induced sediment and pesticide input from orchards into the Lourens river, western cape, South Africa: importance of a single event. Water Research, vol. 35, no. 8, pp. 1869-1876. http://dx.doi.org/10.1016/S0043-1354(00)00458-9. PMid:11337831.

SMITH, L.E.D. and SICILIANO, G.A., 2015. Comprehensive review of constraints to improved management of fertilizers in China and mitigation of diffuse water pollution from agriculture. Agriculture, Ecosystems E Environment, vol. 209, no. 1, pp. 1525. http://dx.doi.org/10.1016/j.agee.2015.02.016.

SUNDARARAJAN, S., KHADANGA, M.K., KUMAR, J.P., RAGHUMARAN, S., VIJAYA, R. and JENA, B.K., 2017. Ecological risk assessment of trace metal accumulation in sediments of Veraval Harbor, Gujarat, Arabian Sea. Marine Pollution Bulletin, vol. 114, no. 1, pp. 592-601. http://dx.doi.org/10.1016/j.marpolbul.2016.09.016. PMid:27817889.

THÉVENOT, D.R., MOILLERON, R., LESTEL, L., GROMAIRE, M.C., ROCHER, V., CAMBIER, P., BONTÉ, P., COLIN, J.L., DE PONTEVÈS, C. and MEYBECK, M., 2007. Critical budget of metal sources and pathways in the Seine River basin (1994-2003) for Cd, $\mathrm{Cr}, \mathrm{Cu}, \mathrm{Hg}, \mathrm{Ni}, \mathrm{Pb}$ and $\mathrm{Zn}$. The Science of the Total Environment, vol. 375, no. 1-3, pp. 180-203. http://dx.doi.org/10.1016/j. scitotenv.2006.12.008. PMid:17267024.

TONI, C., MENEZES, C.C., LORO, V.L., CLASEN, B.E., CATTANEO, R., SANTI, A., PRETTO, A., ZANELLA, R. and LEITEMPERGER, J., 2010. Oxidative stress biomarkers in Cyprinus carpio exposed to commercial herbicide bispyribac-sodium. Journal of Applied
Toxicology, vol. 30, no. 6, pp. 590-595. http://dx.doi.org/10.1002/ jat.1530. PMid:20809548.

TURUNEN, J., MARKKULA, J., RAJAKALLIO, M. and AROVIITA, J., 2019. Riparian forests mitigate harmful ecological effects of agricultural diffuse pollution in medium-sized streams. The Science of the Total Environment, vol. 649, pp. 495-503. http:// dx.doi.org/10.1016/j.scitotenv.2018.08.427. PMid:30176461.

VALKO, M., MORRIS, H. and CRONIN, M.T.D., 2005. Metals, toxicity and oxidative stress. Current Medicinal Chemistry, vol. 12, no. 10, pp. 1161-1208. http://dx.doi.org/10.2174/0929867053764635. PMid:15892631.

WANG, A., KAWSER, A., XU, Y., YE, X., RANI, S. and CHEN, K., 2016. Heavy metal accumulation during the last 30 years in the Karnaphuli River estuary, Chittagong, Bangladesh. SpringerPlus, vol. 5, pp. 2079. http://dx.doi.org/10.1186/s40064-016-3749-1. PMid:28018787.

WANG, J., ZHANG, H., ZHANG, T., ZHANG, R., LIU, R. and CHEN, Y., 2015. Molecular mechanism on cadmium-induced activity changes of catalase and superoxide dismutase. International Journal of Biological Macromolecules, vol. 77, pp. 59-67. http:// dx.doi.org/10.1016/j.ijbiomac.2015.02.037. PMid:25795390.

WU, H., XUAN, R., LI, Y., ZHANG, X., WANG, Q. and WANG, L., 2013. Effects of cadmium exposure on digestive enzymes, antioxidant enzymes, and lipid peroxidation in the freshwater crab Sinopotamon henanense. Environmental Science and Pollution Research International, vol. 20, no. 6, pp. 4085-4092. http:// dx.doi.org/10.1007/s11356-012-1362-6. PMid:23224505.

YE, L., CAI, Q., LIU, R. and CAO, M., 2009. The influence of topography and land use on water quality of Xiangxi River in Three Gorges Reservoir region. Environmental Geology, vol. 58, no. 5, pp. 937942. http://dx.doi.org/10.1007/s00254-008-1573-9.

ZHANG, X., SHEN, G., WANG, Y., HUANG, P., AME, K.H., ZANG, Y. and SHEN, H., 2020. Molecular characterization, expression and enzyme activity of three glutathione S-transferase genes from Eriocheir sinensis under pesticide stresses. Comparative Biochemistry and Physiology. Part C, vol. 230, pp. 108700. http:/I dx.doi.org/10.1016/j.cbpc.2019.108700. PMid:31899308. 